\title{
KEPADATAN BULU BABI (Diadema setosum) PADA EKOSISTEMTERUMBU KARANG DI KARANG KERING PERAIRAN BEDUKANG KABUPATEN BANGKA
}

\section{DENSITY OF Diadema setosum IN CORAL REEF ECOSYSTEM IN DRY CORAL BEDUKANG WATERS OF BANGKA REGENCY}

\author{
Sema Al-Risqia1 ${ }^{*}$, Kurniawan' $^{1}$, Indra Ambalika² \\ ${ }^{1}$ Program Studi Manajemen Sumberdaya Perairan, Fakultas Pertanian Perikanan dan Biologi, \\ Universitas Bangka Belitung \\ 2Program Studi Ilmu Kelautan, Fakultas Pertanian Perikanan dan Biologi, \\ Universitas Bangka Belitung
}

Kampus Terpadu UBB, Gedung Teladan, Bangka, Kepulauan Bangka Belitung, 33172 Indonesia Email: semaalrisqia@gmail.com

\begin{abstract}
ABSTRAK
Perairan Bedukang memiliki tutupan ekosistem Terumbu Karang kering Bedukang 35,9\%. Terumbu karang berfungsi sebagai tempat memijah, mencari makan, daerah asuhan bagi biota laut, dan sebagai sumber plasma nutfah. Kehadiran Diadema setosum pada ekosistem terumbu karang dapat mempengaruhi keseimbangan ekologi di ekosistem terumbu karang suatu perairan. Penelitian ini bertujuan untuk memberikan data kepadatan Diadema setosum pada ekosistem terumbu karang dan memberikan informasi keterkaitan antara kepadatan Diadema setosum dengan karakteristik habitat pada ekosistem terumbu karang di perairan Bedukang Kecamatan Riau Silip Kabupaten Bangka. Penelitian dilakukan pada bulan Maret 2019 di Karang Kering Perairan Bedukang. Metode Belt Transect digunakan untuk pengambilan data Diadema setosum dan Line Intercept Transect untuk pengambilan data terumbu karang. Hasil penelitian didapatkan nilai kepadatan rata-rata Diadema setosum sebanyak 3.708 ind/ha. Persentase tutupan terumbu karang di perairan Bedukang dalam keadaan baik dengan nilai 59,61\%. Keterkaitan antara kepadatan Diadema setosum dengan bentuk pertumbuhan karang atau lifeform karang Acropora Branching (ACB), Acropora Digitate (ACD), Coral Submassive (CS), Turf Algae (TA), dan Other (OT).
\end{abstract}

Kata kunci : Diadema setosum, Kepadatan, Terumbu Karang, Perairan Bedukang

\begin{abstract}
Bedukang waters have a 35,9\% karang kering reef ecosystem cover. Coral reefs function as spawning grounds for marine biota and as a source of germplasm. The presence of Diadema setosum in coral reef ecosystem scan affect the ecological balance in the coral reef ecosystem of a waters. The research aims to analyze data and information on the density of Diadema setosum in coral reef ecosystems, to analyze the association of Diadema setosum density with habitat characteristics in coral reef ecosystems, as preliminary data on Diadema setosum populations in Bedukang waters. The research was conducted on March 2019 in the dry coral waters of Bedukang. Belt Transect method was used for data retrieval of Diadema setosum and Line Intercept Transect for coral reef data retrieval. The results of this research was Diadema setosum density of 3708 individuals/ha. The percentage of coral cover on Bedukang waters is in good condition with a value of $55.79 \%$. The associations between the density of Diadema setosum with the coral lifeform Acropora Branching ( $A C B)$, Acropora Digitate (ACD), Coral Submassive (CS), Turf Algae (TA), dan Other (OT).
\end{abstract}

Keywords :Diadema setosum, Density, Coral reef,Bedukang waters 


\section{PENDAHUluan}

Perairan Bedukang terletak di Desa Deniang Kecamatan Riau Silip, Kabupaten Bangka. Salah satu ekosistem yang terdapat di perairan ini adalah ekosistem terumbu karang. Perairan Bedukang memiliki tutupan ekosistem Terumbu Karang kering Bedukang 35,9\% di kategorikan dalam kondisi sedang berdasarkan Keputusan Menteri Lingkungan Hidup Nomor 04 Tahun 2001 (DKP Kabupaten Bangka, 2014).

Terumbu karang berfungsi sebagai tempat memijah, mencari makan, daerah asuhan bagi biota laut, dan sebagai sumber plasma nutfah. Ekosistem terumbu karang merupakan habitat yang sangat mendukung bagi berbagai jenis fauna invertebrata (Dahuri, 2003). Kerusakan terumbu karang di Perairan Bedukang disebabkan oleh beberapa faktor yaitu gelombang, arus, dan sedimentasi dari muara sungai dan daratan yang sangat mempengaruhi kondisi terumbu karang serta biota-biota yang hidup disekitar terumbu karang. Ancaman sedimentasi menyebabkan karang hidup mati tertutup lumpur yang kemudian ditumbuhi alga. Rusli (2006) menyebutkan bahwa peningkatan jumlah makroalga menimbulkan kompetisi ruang untuk tumbuh bagi hewan karang. Salah satu biota indikator kerusakan karang dapat dilihat dari kepadatan Bulu babi Diadema setosum.

Bulu babi Diadema setosum hidup di daerah pantai berbatu (rockyshore) dan daerah terumbu karang. Hewan ini umumnya hewan nocturnal atau aktif di malam hari, sepanjang siang mereka bersembunyi di celah-celah karang dan keluar pada malam hari untuk mencari makanan (Zakaria, 2013). Bulu babi merupakan herbivora, karena pola makan bulu babi umumnya memakan alga yang terdapat pada terumbu karang. Aktifitas memakan alga akan berpengaruh terhadap keseimbangan makroalga dan ruang tempat terumbu karang untuk berkembang biak. Makroalga adalah pesaing bagi hewan karang dalam memperebutkan sumberdaya ruang (sinar matahari).

Kehadiran Diadema setosum pada ekosistem terumbu karang dapat mempengaruhi keseimbangan ekologi di ekosistem terumbu karang suatu perairan. Namun, belum adanya informasi mengenai kepadatan Diadema setosum pada ekosistem terumbu karang di perairan Bedukang sehingga perlu dilakukan penelitian tentang kepadatan atau sebaran organisme pada ekosistem terumbu karang. Penelitian ini bertujuan yaitu untuk menganalisis kepadatan Diadema setosum pada ekosistem terumbu karang, menganalisis persentase tutupan terumbu karang dengan menggunakan analisis multivariate yaitu Principal Component Analysis (PCA), dan menganalisis keterkaitan antara kepadatan Diadema setosum dengan karakteristik habitat pada ekosistem terumbu karang di perairan Bedukang dengan menggunakan analisis multivariate yaitu Correspondance Analysis (CA) (Bengen, 2000).

\section{METODE PENELITIAN}

Penelitian dilakukan pada bulan Maret 2019. Lokasi penelitian di Karang Kering Perairan Bedukang Desa Deniang Kabupaten Bangka Provinsi Bangka Belitung seperti tersaji pada Gambar 1.

Alat dan bahan yang digunakan pada penelitian ini yaitu thermometer yang digunakan untuk mengukur suhu perairan di lapangan, salinity hydrometer untuk mengukur salinitas perairan, $\mathrm{pH}$ papper untuk mengukur $\mathrm{pH}$ perairan, underwater camerauntuk dokumentasi bawah air, alat dasar selam SCUBA set, roll meter untuk pengukuran koloni karang, dan tali transek ukuran $2 \times 50 \mathrm{~m}$ untuk pengambilan data Diadema setosum.

Penentuan stasiun penelitian menggunakan metode observasi dengan pengamatan langsung di lapangan terhadap kondisi perairan Karang Kering sebagai spot penelitian dengan melakukan kegiatan snorkeling. Penentuan stasiun dibagi menjadi 4 yang mewakili keberadaan Diadema setosum, karang dan alga di perairan Karang Kering.

Pengambilan data karang dilakukan dengan metode LIT (Line Intercept Transect) (English et al., 1994). Metode ini digunakan untuk mengetahui persen tutupan terumbu karang bentuk pertumbuhan atau genus karang (English et al., 1994), yang kemudian akan diidentifikasi sampai tingkat genus dengan Veron (2000). Keunggulan pada metode ini yaitu tingkat akurasi data dapat diperoleh dengan baik, namun kekurangan pada metode ini yaitu membutuhkan tenaga peneliti yang banyak, waktu pengamatan yang lama, dan biaya yang relatif lebih besar. Prosedur kerja diawali dengan pemasangan transek garis dengan cara membentangkan roll meter sepanjang $10 \mathrm{~m}$ sebanyak 6 kali dengan interval $10 \mathrm{~m}$ mengikuti pola kedalaman garis kontur sehingga total panjang transek garis sepanjang $60 \mathrm{~m}$ setiap stasiun. 


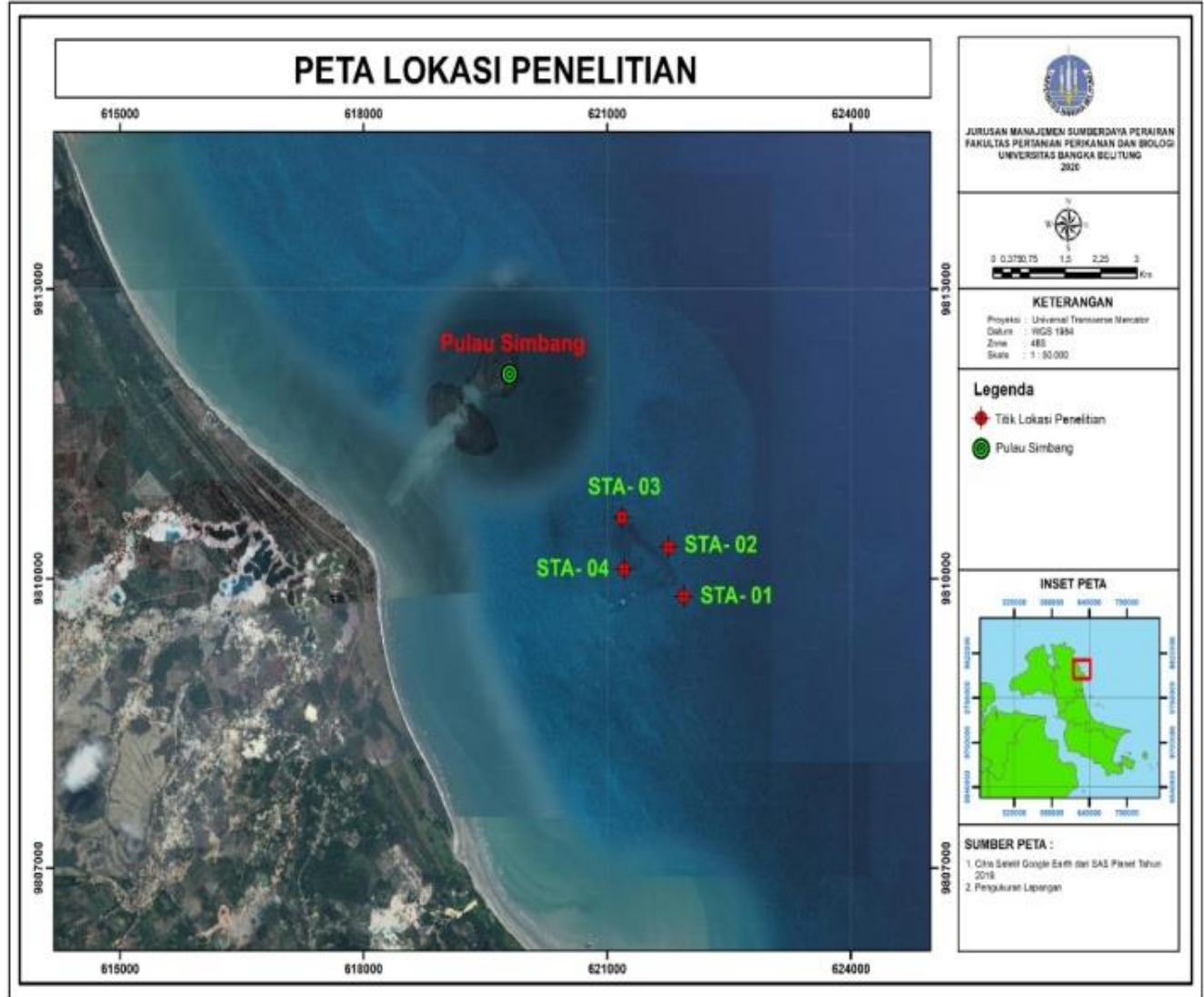

Gambar 1. Peta Lokasi Penelitian

Pengambilan data Diadema setosum menggunakan metode belt transect yang Panjang line transect total yaitu $110 \mathrm{~m}$. Prosedur kerja metode ini yaitu menggunakan belt transec tdengan luas $1 \mathrm{x}$ $10 \mathrm{~m}^{2}$ sebanyak 6 kali dengan interval antar plot $10 \mathrm{~m}$ dan menghitung setiap Diadema setosum yang berada dalam jarak $0,5 \mathrm{~m}$ pada kedua sisi garis, pada kedalaman 2-3 m.Total luas pengamatan dalam satu stasiun yaitu $60 \mathrm{~m}^{2}$ yang didapat dari luasan transect. Dilakukan ulangan pada yang sama pada stasiun berikutnya.

Data parameter lingkungan diambil secara langsung di lapangan pada setiap lokasi pengamatan penelitian. Parameter yang diukur terdiri dari suhu, kecerahan, kecepatan arus, salinitas $\mathrm{pH}$, dan DO (Dissolved Oxygen), dan TSS (Total Suspended solid) yang akan dianalisa di Laboratorium Manajemen Sumberdaya Perairan, Universitas Bangka Belitung.

\section{HASIL DAN PEMBAHASAN}

Hasil rata-rata kepadatan Diadema setosum yang diperoleh di perairan Bedukang adalah 3.708 individu/ha. Kepadatan Diadema setosum tertinggi terdapat di stasiun 4 sebanyak 4000 individu/ha.
Kepadatan Diadema setosum di perairan Bedukang dapat dilihat pada Tabel 1.

Tabel 1. Kepadatan Diadema setosum di perairan Bedukang

\begin{tabular}{lll}
\hline Stasiun & $\begin{array}{l}\text { jumlah } \\
\text { individu }\end{array}$ & $\begin{array}{l}\text { Kepadatan } \\
\text { ind/ha }\end{array}$ \\
\hline 1 & 20 & 3.333 \\
2 & 22 & 3.666 \\
3 & 23 & 3.833 \\
4 & 24 & 4.000 \\
\hline $\bar{x}_{\text {ind/ha }}$ & & 3.708 \\
\hline
\end{tabular}

Hasil penelitian kepadatan Diadema setosumpada stasiun 1 ditemukan 3333 individu/ha, stasiun 2 ditemukan 3666 individu/ha, stasiun 3 ditemukan 3833 individu/ha, stasiun 4 ditemukan 4000 individu/ha seperti yang terlihat pada Tabel 4 . Nilai kepadatan rata-rata bulu babi Diadema setosum di perairan Bedukang ditemukan sebanyak 3708ind/ha dari 4 stasiun, relatif lebih rendah apabila dibandingkan dengan yang ditemukan oleh Ferizal (2011) di Karang Kering Rebo, Bangka sebanyak 5240 individu/ha; di Pulau Ketawai dan Pulau Gusung Asam, Bangka Tengah dengan nilai masing-masing sebanyak 7150 individu/ha 
dan 7550 individu/ha. Perbedaan nilai kepadatan bulu babi di setiap stasiun pengamatan disebabkan perbedaan lokasi habitat dan dipengaruhi faktor biologis. Latuconsina (2016) menyebutkan bahwa kehadiran suatu organisme sangat tergantung pada keadaan ekosistem atau lingkungan ekologi yang ada.

Kepadatan Diadema setosum tertinggi yaitu pada stasiun 4 sebanyak 4000 individu/ha. Tingginya kepadatan pada stasiun ini dipengaruhi oleh kondisi habitat yang cocok untuk kehidupan Diadema setosum. Hal ini disebabkan karena adanya dukungan berbagai faktor makanan antara lain banyaknya mikroorganisme yang menempel pada karang yang merupakan makanan bulu babi. Kelimpahan Diadema setosum dikarenakan banyaknya turf algae yang merupakan sumber makanan bagi bulu babi, penutupan turf algae pada stasiun 4 sebesar 19,17\%. Menurut Zakaria (2013) turf algae merupakan makanan yang digemari oleh bulu babi Diadema setosum. Secara geografis letak stasiun 4 berada pada wilayah terlindung sehingga kecepatan arus relatif kecil oleh karena itu bulu babi lebih banyak ditemukan pada stasiun ini. Radjab (2000) menyebutkan bahwa bulu babi menyukai perairan yang jernih dan tenang. Tingginya persentase tutupan karang hidup pada stasiun 4 sebesar $73,45 \%$ juga menjadi penyebab tingginya kepadatan bulu babi. Hal ini disebabkan terumbu karang sebagai tempat berlindung dan penyedia sumber makanan bagi bulu babi jenis ini.

Kepadatan Diadema setosum terendah terdapat pada stasiun 1 dengan nilai 3.333 individu/ha. Rendahnya nilai kepadatan tersebut dipengaruhi oleh kedalaman perairan. Hal ini berhubungan dengan faktor cahaya, suhu, arus dan gelombang. Pada saat surut terendah maka karang akan muncul kepermukaan perairan sehingga sinar matahari secara langsung menembus perairan. Hempasan gelombang relatif kuat yang dapat menyebabkan teraduknya substrat perairan sehingga perairan menjadi keruh. Bulu babi menyukai perairan yang jernih dan tenang (Radjab, 2000). Kecepatan arus pada stasiun ini termasuk kategori arus sedang. Bahwa kecepatan arus terdiri atas 4 kelas yaitu kelas arus lambat dengan kecepatan pada kisaran $0-5 \mathrm{~cm} / \mathrm{s}$, kelas arus sedang dengan kecepatan pada kisaran $>15-$ $30 \mathrm{~cm} / \mathrm{s}$, kelas arus cepat dengan kecepatan pada kisaran $>30-50 \mathrm{~cm} / \mathrm{s}$ dan kelas arus sangat cepat dengan kecepatan di atas 50 $\mathrm{cm} / \mathrm{s}$. Menurut Aziz (1995) Diadema setosum lebih menyukai kisaran kecepatan arus yang relatif lamban. Hal ini dikarenakan hubungannya dengan pergerakan dari Diadema setosum itu sendiri. Menurut Kawamata (2010) bahwa perilaku makan bulu babi sangat dipengaruhi oleh gelombang air sehingga mempengaruhi pergerakannya untuk mencari makan.

Kepadatan Diadema setosum pada stasiun 2 sebesar 3667 individu/ha dan stasiun 3 sebesar 3833 individu/ha. Stasiun 2 dan 3 memiliki nilai kepadatan yang lebih sedikit dibandingkan dengan stasiun 4 . Ketersediaan makanan yang banyak menyebabkan terjadinya kompetisi di kedua stasiun ini. Hal ini ditunjukkan dari tingginya nilai persentase tutupan turf algae yaitu sebesar $47,07 \%$ dan $28,68 \%$. Sugiarto dan Supardi (1995) menyebutkan Diadema setosum ditemukan mendominasi di habitat yang ditempati, dominansi tersebut terjadi karena disebabkan cara hidup mengelompok dalam kelompok yang besar.

Hasil persen tutupan terumbu karang yang terdapat di Perairan Bedukang pada masing-masing stasiun ditampilkan pada Tabel 2. Kondisi tutupan terumbu karang di Perairan Bedukang pada stasiun 1 dalam keadaan baik dengan nilai $71,33 \%$, stasiun 2 dalam keadaan sedang dengan nilai $42,77 \%$, stasiun 3 dalam kondisi baik dengan nilai $50,90 \%$, dan stasiun 4 dalam kondisi baik dengan nilai $73,45 \%$.

Hasil pengamatan persentase tutupan karang hidup di Perairan Bedukang stasiun 1 sebesar $71,33 \%$ termasuk dalam kategori baik, stasiun $242,77 \%$ termasuk dalam kategori sedang, stasiun 3 sebesar 50,90\% termasuk dalam kategori baik, stasiun 4 sebesar 73,45\% termasuk dalam kategori baik berdasarkan Keputusan Menteri Lingkungan Hidup No 4 Tahun 2001. Persentase tutupan terumbu karang hidup tertinggi terdapat pada stasiun 1, 3, dan 4 yang termasuk ke dalam kategori baik. Tingginya persentase tutupan karang hidup dipengaruhi oleh kondisi lingkungan perairan yang baik untuk pertumbuhan karang itu sendiri. Keadaan ini didukung dengan nilai DO yang tinggi merupakan nutrient karang untuk tumbuh dan berkembang.

Stasiun 2 termasuk dalam kategori sedang. Terumbu karang di stasiun 2 dan 3 memiliki nilai tutupan turf algae yang relatif lebih tinggi dibandingkan stasiun 1 dan 4 dengan nilai masing-masing $47,07 \%$ dan $28,68 \%$. Tingginya nilai persentase tutupan turf algae berpotensi menjadi saingan utama bagi ruang hidup terumbu karang. Timotius 
(2003) menyebutkan bahwa salah satu faktor alami yang mengakibatkan hewan karang mati yakni adanya kompetitor karang yang salah satunya disebabkan oleh algae.

Keberadaan algae didaerah terumbu karang ini juga dapat menghambat pertumbuhan karang, mikro algae (Zooxanthella) yang terdapat di dalam polip karang akan kalah bersaing dengan algae yang telah berkembang dengan cepat tersebut dalam hal memperebutkan nutrient dalam perairan. Terumbu karang yang ditumbuhi algae dalam jangka waktu yang lama akan menyebabkan perubahan ekosistem dari ekosistem terumbu karang menjadi ekosistem hamparan algae.

Bulu babi Diadema setosum merupakan indikator lingkungan dari ekosistem terumbu karang. Penambahan nilai kepadatan bulu babi akan diikuti dengan pengurangan nilai tutupan makroalgae. Hal tersebut karena bulu babi merupakan hewan herbivora dan salah satu makanannya adalah makroalgae. Bulu babi merupakan spesies kunci bagi ekosistem terumbu karang. Hal ini didukung dengan pendapat Nystrom et al., (2000) yang menyatakan bulu babi merupakan salah satu spesies kunci bagi komunitas terumbu karang. Hal ini disebabkan bulu babi adalah salah satu pengendali populasi makroalgae.

Penelitian menunjukkan ditemukannya 14 jenis lifeform karang yaitu Acropora
Branching (ACB), Acropora Digitate (ACD), Acropora Tabulate (ACT), Coral Encrusting (CE), Coral Massive (CM), Coral Folliose (CF), Coral Mushroom (CMR) Coral Submassive (CS), Dead Coral Algae (DCA), Turf Algae (TA), Others (OT), Rubble (R), Sand (S), dan Silt (Si). Hasil pengamatan persentase tutupan karang bentuk pertumbuhan folliose dan massive paling mendominasi. Dominasi karang massive di daerah reef flat dikarenakan karang massive atau karang batu mempunyai mekanisme ketahanan diri pada kondisi lingkungan yang ekstrim. Morfologi karang berbentuk massive merupakan cara efektif bagi biota karang untuk mempertahankan diri dari hempasan gelombang. Storlazzi et al. (2003) menyebutkan ada keterkaitan yang sangat kuat antara bentuk morfologi karang dengan energi gelombang pada suatu perairan. Karang massive mempunyai kemampuan menyimpan air pada columella pada saat surut terendah sehingga karang ini akan terhindar dari kematian akibat dari paparan sinar matahari secara langsung. Perairan Pulau Bangka didominasi oleh karang massive. Nilai kepadatan Diadema setosum dapat dipengaruhi oleh parameter lingkungan (suhu, kecerahan, TSS, arus, $\mathrm{pH}$, salinitas, kedalaman dan DO). Data parameter fisikakimia dapat dilihat pada Tabel 3.

Tabel 2. Persentase tutupan (lifeform) terumbu karang di Perairan Bedukang

\begin{tabular}{llllll}
\hline \multirow{2}{*}{ Categories } & \multicolumn{1}{c}{ CoralLifeform } & \multicolumn{4}{c}{ Stasiun } \\
\cline { 3 - 6 } Acropora & AcroporaBranching (ACB) & 0,37 & 4,23 & 1,20 & 1,32 \\
& AcroporaDigitate (ACD) & 8,13 & 9,02 & 5,55 & 6,90 \\
& AcroporaTabulate (ACT) & 1,67 & 0 & 0 & 2,27 \\
& CoralEncrusting (CE) & 5,85 & 0,53 & 0 & 2,97 \\
Non Acropora & CoralFolliose (CF) & 27,60 & 14,98 & 35,78 & 50,72 \\
& CoralMassive (CM) & 25,73 & 7,73 & 7,23 & 2,88 \\
DeadCoral & CoralMushroom (CMR) & 1,98 & 0,50 & 0,97 & 6,40 \\
Algae & CoralSubmassive (CS) & 0 & 5,77 & 0,17 & 0 \\
Others & DeadCoralAlgae (DCA) & 20,60 & 8,10 & 12,00 & 0,43 \\
\multirow{3}{*}{ Abiotik } & TurfAlgae(TA) & 6,62 & 47,07 & 28,68 & 19,17 \\
& Other (OT) & 0,07 & 2,07 & 0,33 & 0,00 \\
& Rubble (R) & 1,18 & 0 & 5,68 & 5,52 \\
& Sand (S) & 0 & 0 & 2,40 & 1,43 \\
& Silt (Si) & 0,20 & 0 & 0 & 0 \\
\hline
\end{tabular}


Tabel 3. Parameter fisika kimia di lokasi pengamatan

\begin{tabular}{clcccc}
\hline No & \multicolumn{1}{c}{ Parameter } & St1 & St2 & St3 & St4 \\
\hline 1 & Salinitas (\%o) & 30 & 30 & 31 & 30 \\
2 & Kecerahan (\%) & 100 & 100 & 100 & 100 \\
3 & Suhu ${ }^{\circ}$ & 31 & 30 & 31 & 31 \\
4 & Arus (m/s) & 0,078 & 0,090 & 0,088 & 0,080 \\
5 & Kedalaman (m) & 2,46 & 3,01 & 2,1 & 3,11 \\
6 & TSS (mg/L) & 55,4 & 32,6 & 82,3 & 77,2 \\
7 & pH & 8 & 8 & 8 & 8 \\
8 & DO (mg/L) & 7,1 & 6,9 & 6,6 & 7,5 \\
\hline
\end{tabular}

Parameter kualitas air sangat berpengaruh terhadap kepadatan Diadema setosum di perairan. Dari pengamatan yang dilakukan pada lokasi penelitian seperti salinitas, kecerahan, suhu, arus, kedalaman, TSS, pH, DO. secara umum masih dalam batas normal yang bisa di toleransi oleh karang dan Diadema setosum.

Salinitas perairan pada lokasi penelitian berkisar antara 30-31\%o. Nilai tesebut masih dalam kondisi yang cocok untuk kehidupan Diadema setosum. Nontji (2002) menyatakan bahwa pertumbuhan normal Diadema setosum yaitu kisaran salinitas antara 30$34 \%$. Penelitian serupa dimana nilai salinitas berkisar antara 27-34\%o (Thamrin, 2006); 14-31\%o (Melay et al., 2015); 34-35\%o (Zakaria, 2013); 30-31\%o (Miala et al., 2015); 30-34\%o (Mustaqim et al., 2013); 30$31 \%$ (Purwandatama et al., 2014). Aziz (1994) menyatakan bulu babi tidak tahan terhadap salinitas rendah, apabila kisaran salinitas di suatu perairan berkisar antara $23 \%$-26\%o, maka akan berakibat pada perubahan pigmen warna, duri-duri akan rontok, dan bulu babi akan menjadi tidak aktif, tidak mau makan dan pada akhirnya akan mengalami kematian. Kisaran salinitas untuk pertumbuhan karang dan lamun berkisar 25-35\%o. Hal tersebut mempengaruhi secara tidak langsung terhadap perkembangan dan kelimpahan bulu babi.

Suhu perairan berkisar antara $30-31^{\circ} \mathrm{C}$. Nilai tersebut dalam kondisi normal untuk kehidupan Diadema setosum. Nybakken (1992) menyebutkan kisaran suhu yang mendukung bagi pertumbuhan karang dan biota yang hidup disekitarnya adalah kisaran $25-35^{\circ} \mathrm{C}$. Nilai suhu dari beberapa penelitian serupa berkisar antara 25-30॰C (Melay et al., 2015); 28-30.C (Purwandatama et al., 2014); 28-32॰C (Zakaria, 2013); 28-31.C (Miala et al., 2015); dan 28-30.C (Mustaqim et al., 2013). Suhu perairan tersebut mendukung pertumbuhan dan kehidupan karang, lamun dan bulu babi. Bulu babi tidak memiliki adaptasi khusus terhadap peningkatan suhu di atas ambang batas maksimum yaitu $36^{\circ} \mathrm{C}$ sampai $40^{\circ} \mathrm{C}$. Selain itu juga bahwa pada suhu dingin di bawah ambang batas minimum juga dapat mengakibatkan kematian massal biota laut yang hidup didaerah subtropis.

Kecepatan arus berkisar antara 0,078-0,090 m/s. Nilai tersebut dalam kondisi normal dan masih dapat ditoleransi untuk kehidupan Diadema setosum. Penelitian serupa yang dilakukan oleh mendapatkan nilai kecepatan arus 0,046$0,056 \mathrm{~m} / \mathrm{s}$ (Umar, 2006); 0,04-0,18 m/s (Mustaqim et al., 2013); 0,08-1,02 m/s (Purwandatama et al., 2014); dan 0,6-0,9 $\mathrm{m} / \mathrm{s}$ (Miala et al., 2015). Arus mempunyai pengaruh positif maupun negatif terhadap kehidupan biota perairan (Romimohtarto \& Juwana, 2007). Arus memiliki pengaruh besar terhadap aerasi, transportasi nutrien, dan pengadukan air. Pengadukan air berperan untuk menghindari fluktuasi suhu yang besar. Peranan lain dari arus adalah menghindari akumulasi lumpur dan epifit yang melekat pada thallus yang dapat mempengaruhi pertumbuhan alga (Ambas, 2006).

Nilai TSS berkisar antara 32,6-82,3 $\mathrm{mg} / \mathrm{L}$ pada kondisi surut. Nilai TSS tersebut sangat tinggi dimana menurut Keputusan Menteri Lingkungan Hidup nomor 51 tahun 2004 tentang Baku Mutu Air Laut untuk Biota Laut nilai TSS untuk ekosistem terumbu karang sebesar 20 $\mathrm{mg} / \mathrm{L}$ yang mengindikasikan Diadema setosum hidup dalam kondisi normal. Tingginya nilai TSS menyebabkan koloni terumbu cepat ditumbuhi oleh turf algae yang mendominansi. Makro algae sendiri akan menjadi sumber makanan bagi Diadema setosum sehingga cepat mendominansi koloni yang ditumbuhi makro algae (Melay et al., 2015; Purwandatama et al., 2014; Zakaria, 2013; Mustaqim et al., 2013; Miala 
et al.,2015). TSS dapat digunakan sebagai indikator kekeruhan dan laju sedimentasi di perairan yang merupakan faktor lingkungan yang penting bagi kehadiran biota bentonik termasuk karang dan bulu babi (Firdaus etal., 2010).

Kedalaman perairan berkisar antara 2,1-3,11 m. nilai tersebut termasuk dalam kondisi optimal untuk pertumbuhan Diadema setosum. Penelitian serupa mengenai Diadema setosum, kedalaman berkisar antara 1,98-3,77 m (Miala et al., 2015); 2-7 m (Mustaqim et al., 2013); 0-19 m (Zakaria, 2013); 1,62-4,77 m (Purwandatama et al., 2014). Kedalaman perairan berkorelasi positif dengan kecerahan. Kecerahan sangat berhubungan dengan penetrasi cahaya, kecerahan yang tinggi membuat penetrasi cahaya akan cukup tinggi, Kecerahan pada lokasi penelitian didapatkan hingga ke dasar perairan. Kecerahan perairan akan mencapai maksimal apabila angin yang bertiup tidak begitu kencang, kecepatan arus rendah sehingga tidak terjadi pengadukan yang menyebabkan air menjadi keruh (Bonnel, 2003). Marsuki (2012) menyebutkan tingkat kecerahan sangat penting bagi pertumbuhan organisme karang, karena cahaya adalah salah satu faktor yang paling penting yang membatasi terumbu karang sehubungan dengan laju fotosintesis oleh zooxanthellae yang bersimbiosis pada jaringan karang yang dapat berpengaruh kepada sumber makan bagi biota herbivora seperti bulu babi.

DO perairan berkisar antara 6,6-7,5 mg/L. Nilai tersebut merupakan kondisi optimal untuk pertumbuhan Diadema setosum. Hal ini diperkuat oleh Keputusan Menteri Lingkungan Hidup nomor 51 tahun 2004 tentang Baku Mutu Air Laut untuk Biota Laut nilai DO untuk ekosistem terumbu karang sebesar $>5 \mathrm{mg} / \mathrm{L}$. Penelitian serupa mendapatkan nilai DO sebesar 7-8,4 mg/L (Zakaria, 2013). Nilai DO merupakan salah satu faktor yang mempercepat pertumbuhan algae (Ghufran dan Kordi, 2010).

Hasil Analisis Faktorial Koresponden (CA) menunjukkan preferensi habitat Diadema setosum di 4 stasiun pengamatan terpusat pada dua sumbu dengan sumbu utama $F 1(51,44 \%)$ dan sumbu F2 $(39,78 \%)$ dengan nilai ragam total $(91,22 \%)$ disajikan pada Gambar 2. Hasil CA mengelompokkan menjadi tiga kelompok yaitu kelompok pertama sumbu F1 (positif) stasiun 2 dan stasiun 3 dicirikan dengan kepadatan, Acropora Digitate (ACD), Acropora Branching (ACB), Turf Algae (TA), Coral Submassive (CS), dan Others (OT). Kelompok kedua sumbu F2 (positif) stasiun 1 dicirikan dengan Coral Encrusting (CE), Coral Massive (CM), Dead Coral Algae (DCA), dan Silt (Si). Kelompok ketiga sumbu F2 (negatif) stasiun 4 dicirikan dengan Acropora Tabulate (ACT), Coral Folliose (CF), Coral Mushroom (CMR), Rubble (R), dan Sand (S).

Hasil analisis faktorial koresponden (CA) di perairan Bedukang terdapat tiga kelompok yang mencirikan preferensi habitat berdasarkan kepadatan Diadema setosum ditampilkan pada Gambar 6. Hasil CA mengelompokkan menjadi tiga kelompok. Kelompok pertama yaitu stasiun 2 dan stasiun 3 dicirikan dengan kepadatan, Acropora Digitate (ACD), Acropora Branching (ACB), Turf Algae (TA), Coral Submassive (CS), dan Others (OT). Aziz (1996) mengatakan terdapat 3 jenis substrat yang dapat ditemukan Diadema setosum di ekosistem terumbu karang, yaitu pada karang hidup, karang mati, dan pecahan karang. Kepadatan Diadema setosum berhubungan kuat dengan keberadaan karang bercabang seperti Acropora. Hal ini diperkuat oleh Purwandatama (2014) yang mengatakan karang bercabang (branching) seperti Acropora dan pecahan karang merupakan daerah yang paling banyak ditemukan bulu babi secara berkelompok dikarenakan banyaknya makanan dan celah tempat berlindung bulu babi dari serangan predator. Aziz (1996) juga mengatakan terumbu karang yang berukuran besar dan memiliki percabangan yang rapat seperti Acropora merupakan tempat hidup ideal untuk biota komensal seperti Diadema setosum. Adanya turf algae merupakan salah satu makanan yang disukai oleh Diadema setosum juga menyebabkan melimpahnya keberadaan bulu babi di stasiun pengamatan ini. Menurut Purwandatama et al. (2014), bulu babi menempati daerah rataan terumbu, daerah pertumbuhan algae, dan daerah tubir karang. Di daerah rataan terumbu dan daerah pertumbuhan algae, bulu babi biasanya hidup secara mengelompok dalam kelompok yang besar. Kehidupan mengelompok merupakan adaptasi khusus untuk melindungi diri dari serangan predator dan mempermudah terjadinya perkawinan. Kelompok kedua yaitu stasiun 1 dicirikan dengan Coral Encrusting (CE), Coral Massive (CM), Dead Coral Algae (DCA), dan Silt (Si). Kelimpahan Diadema setosum paling sedikit ditemukan di stasiun pengamatan ini. Hal ini dikarenakan rendahnya nilai turf algae di stasiun ini yaitu sebesar 6,62\% tidak memenuhi kebutuhan makanan Diadema 
setosum. Kepadatan Diadema setosum juga tidak mempunyai nilai korelasi dengan karang yang mempunyai bentuk pertumbuhan atau lifeform karang massive. Purwandatama et al.,(2014) mengatakan kelimpahan bulu babi sedikit ditemukan di daerah karang massive dan pasir dikarenakan tidak adanya ketersediaan makanan yang cukup dan tempat berlindung dari serangan predator di daerah tersebut.

Kelompok ketiga yaitu stasiun 4 dicirikan dengan Acropora Tabulate (ACT), Coral Folliose (CF), Coral Mushroom (CMR), Rubble (R), dan Sand (S). Kepadatan Diadema setosum paling banyak ditemukan di stasiun pengamatan ini namun nilai kepadatan tidak berkorelasi dengan bentuk pertumbuhan atau lifeform karang. Selain itu rendahnya nilai turf algae $(19,17 \%)$ di stasiun pengamatan ini juga menyebabkan terjadinya kompetisi dalam memperoleh makanan. Zakaria (2013) mengatakan Diadema setosum memiliki persebaran zona yang lebih banyak dibandingkan jenis lainnya. Diadema setosum dapat ditemukan di berbagai zona dalam ekosistem terumbu karang antara lain : zona pasir, zona pertumbuhan algae, zona lamun sampai daerah tubir. Diadema setosum dewasa banyak ditemukan di daerah tubir dikarenakan banyaknya lubang-lubang lebih besar sebagai tempat berlindung dari predator sedangkan ukuran kecil ditemukan pada daerah karang mati yang dengan dengan daerah pasang surut.

Diadema setosum merupakan hewan dari filum Echinodermata yang mudah ditemukan pada daerah pantai, dan menjadi spesies penting di ekosistem terumbu karang. Kehadiran Diadema setosum sebagai pengendali makroalga, sementara makroalga adalah pesaing bagi hewan karang dalam memperebutkan sumberdaya ruang. Diadema setosum akan merusak lingkungan jika tanpa makroalga dan asosiasi fauna (Zakaria, 2013). Hudaet al. (2017) menyebutkan Diadema setosum dikenal sebagai spesies indikator dari lingkungan yang tercemar memiliki sensivitas yang tinggi terhadap logam berat kadmium.

Eksploitasi langsung dari alam spesies Diadema setosum tidak dianjurkan karena dikhawatirkan akan mengganggu kestabilan ekosistem terumbu karang perairan Bedukang, mengingat peran spesies tersebut sebagai organisme indikator perairan.

Symmetric plot

(axes F1 and F2: 91,22 \%)

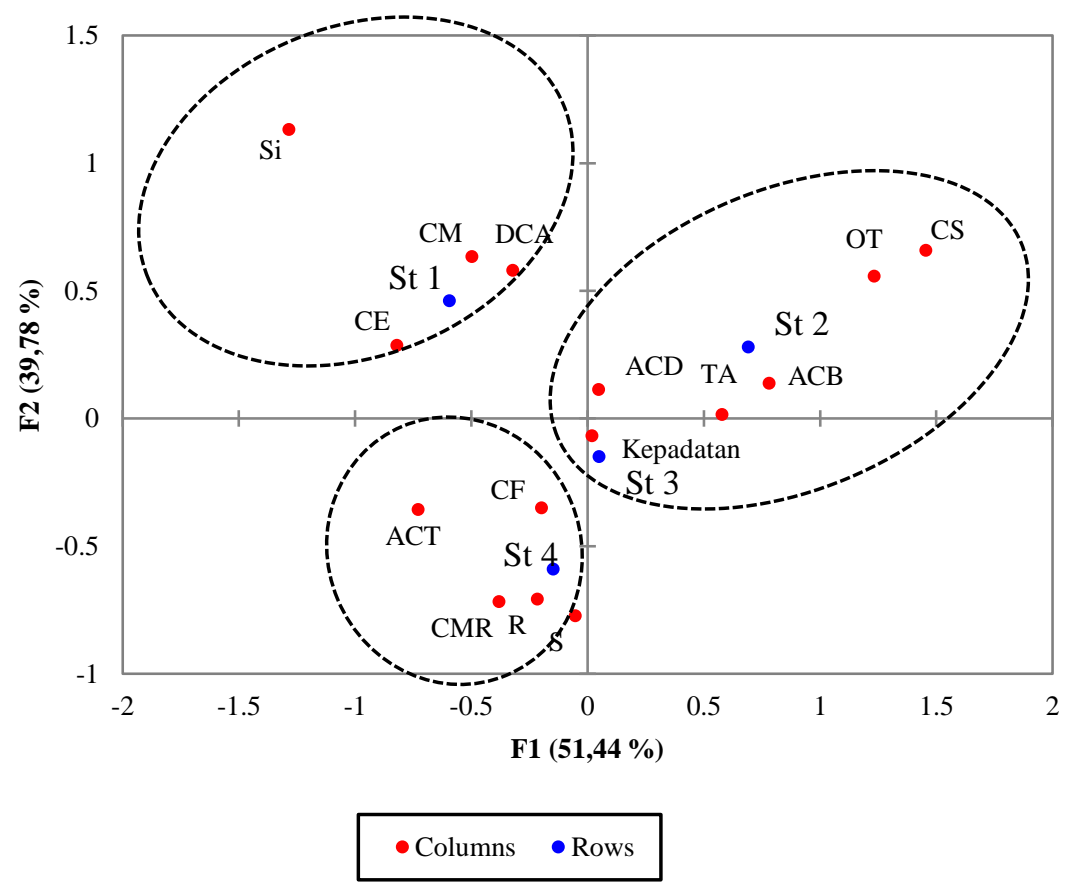

Gambar 2. Correspondent Analysis (CA) kepadatan Diademasetosum dengan karakteristik habitat. Keterangan: $\mathrm{ACB}=$ AcroporaBranching; $\mathrm{ACD}=$ AcroporaDigitate; $\mathrm{ACT}=$ AcroporaTabulate; $\mathrm{CE}=$ Coral Encrusting; $\mathrm{CF}=$ Coral Folliose; $\mathrm{CM}=$ Coral Massive; $\mathrm{CMR}=$ CoralMushroom; $\mathrm{CS}=$ CoralSubmassive; $\mathrm{TA}=$ turf algae; $\mathrm{DCA}=$ dead coral algae; $\mathrm{R}=$ rubble; $\mathrm{S}=$ sand; $\mathrm{SI}=$ silt; $\mathrm{OT}=$ other . 
Pemanfaatan yang bisa dilakukan terhadap bulu babi Diadema setosum di lokasi pengamatan tersebut adalah menjadikannya sebagai sumber benih yang dapat disalurkan untuk kegiatan budidaya bulu babi. Kegiatan budidaya Diadema setosum disarankan untuk dilakukan di lokasi pengamatan karena kondisi habitatnya mendukung, selain itu bisa menjadi peluang penghasilan sampingan para nelayan di daerah sekitar.

\section{KESIMPULAN}

\section{Nilai kepadatan rata-rata Diadema} setosum yang ditemukan di Perairan Bedukang sebanyak 3708 individu/ha. Kepadatan tertinggi pada stasiun 4 sebesar 4000 individu/ha dan kepadatan terendah pada stasiun 1 sebesar 3333 individu/ha. Persentase tutupan terumbu karang di perairan Bedukang dalam keadaan baik. Stasiun 1, stasiun 3, dan stasiun 4 dalam keadaan baik dengan nilai tutupan karang berturut-turut $71,33 \%$, 50,90\%, dan $73,45 \%$. Stasiun 2 dalam keadaan sedang dengan nilai tutupan karang 42,77\%. Parameter lingkungan di Perairan Bedukang masih dalam batas normal yang bisa ditoleransi Diadema setosum. Korelasi antara kepadatan Diadema setosum dengan bentuk pertumbuhan karang atau lifeform di Perairan Bedukang menunjukkan bahwa Diadema setosum menyukai lifeform karang Acropora Branching (ACB), Acropora Digitate (ACD), Coral Submassive (CS), Turf Algae (TA), dan Other (OT).

\section{REFERENSI}

Ambas. 2006, Kondisi Perairan untuk Pertumbuhan Caulerpa racemosa. Universits Indonesia. Jakarta

Aziz, A. 1994. Pengaruh Salinitas Terhadap Sebaran Fauna Echinodermata. Jurnal Oseana, 19(2):23-32.

Aziz, A. 1995. Beberapa catatan Tentang Bulu Babi Meliang. Jurnal Oseana, 20(3):11-19

Aziz, A. 1996. Habitat \& Zonasi Fauna Ekhinodermata di Ekosistem Terumbu Karang. Jurnal Oseana, 21(2):33-43

Bengen, D.G. 2000. Teknik Pengambilan Contoh \& Analisis Data Biofisik Sumber Daya Pesisir. PK-SPL IPB. Bogor.

Dahuri, R. 2003. Keanekaragaman Hayati Laut, Aset Pembangunan Indonesia. PT. Gramedia Pustaka Utama. Jakarta.

English, S., Willkinson, C. \& Baker, V. 1994. Survey Manual for Tropical Marine
Resources. ASEAN - Australia Marine Science Project : Living Coastal Resource Ferizal J. 2011. Kelimpahan Bulu Babi (Diadema setosum) di Karang Kering Rebo, Kabupaten Bangka. Bangka: Fakultas Pertanian Perikanan dan Biologi, Universitas Bangka Belitung.

Firdaus, F.R., Hardika, R., Syahputra, D., Oktavian, R. \& Helfinalis. 2010. Karakteristik Endapan Sedimen Laut dan Total Suspended Solid (TSS) di perairan Bangka. Di dalam : Direktorat Kelembagaan, Direktorat, Jenderal Pendidikan Tinggi, Kementrian Pendidikan Nasional dan LIPI. Perairan Propinsi Kepulauan Bangka-Belitung : Sumberdaya Hayati Laut dan Oseanografi. Jakarta: LIPi Press. HIm 125-135.

Ghufran, M. \& Kordi, K.M.G.H. 2010. Ekosistem Terumbu Karang. PT Rineka Cipta. Jakarta: 73-76.

Giyanto, Manuputty, A.E.W., Abrar, M., Siringringo, R.M., Suharti, S.R., Wibowo, K., Edrus, I.N., Arbi, U.Y., Cappenberg, H.A.W., Sihalolo, H.F., Tuti, Y. \& Zulfiana D. 2014. Panduan Monitoring Kesehatan Terumbu Karang. COREMAP CTI LIPI. Jakarta

Huda, M.A., Sudarmaji, S. \& Fajariyah, S. 2017. Keanekaragaman Jenis Echinoidea di Zona Intertidal Pantai Jeding Taman Nasional Baluran. Berkala Sainstek. 5(2): 61-65.

Kawamata S. 2010. Inhibitory Effects of Wave Action on Destructive Grazing by Sea Urchins. a review Bull Fish Res Agen 32: 95-102.

Latuconsina, H. 2016. Ekologi Perairan Tropis : Prinsip Dasar Pengelolaan Sumber Daya Hayati Perairan. Yogyakarta: Gadjah Mada University Press.

Marsuki, I.D., Baru, S. \& Ratna, D.P. 2012. Kondisi Terumbu karang dan Kelimpahan Kima di Perairan Pulau Indo. Jurnal Mina Laut Indonesia, 1(01):61-72

Melay, S., Tuapattinaya, P.M.J. \& Sangadji, F. 2015. Kajian Faktor Lingkungan dan Identifikasi Filum Mollusca, Filum Echinodermata di Ekosistem Padang Lamun Perairan Pantai Negeri Tulehu Kabupaten Maluku Tengah. Jurnal Biopendix, 1(2):113-120

Miala, I., Pratomo, A., \& Irawan, H. 2015. Hubungan Antara Bulu Babi, Makroalgae Dan Karang Di Perairan Daerah Pulau Pucung. Repository Umrah. 2015.

Mustaqim, M.R, Ruswahyuni \& Suryanti. 2013. Kelimpahan Jenis Bulu Babi 
(Echinoidae, Leske 1778) Di Perairan Si Jago-Jago, Tapanuli Tengah. Diponegoro Journal of Maquares, 2(4):61-70

Nontji A. 2002. Laut Nusantara. Jakarta: Djambatan.

Nybakken, J.W. 1992. Biologi Laut Sebagai Suatu Pendekatan Ekologis. PT. Gramedia. Jakarta.

Nyström, M., Folke, C. \& Moberg, F. 2000. Coral reef disturbance and resilience in a human-dominated environment. Trends in ecology\&evolution, 15(10):413-417.

Purwandatama, R.W, Churun, A. \& Suryanti. 2014. Kelimpahan Bulu Babi (Sea Urchin) Pada Karang Massive dan Branching Di Daerah Rataan dan Tubir Di LegonBoyo, Pulau Karimunjawa, Taman Nasional Karimunjawa. Diponegoro Journal of Maquares. 3(1):17-26

Radjab AW. 2000. Sebaran dan Kepadatan Bulu Babi di Perairan KepulaunPaidodo, Biak Irian Jaya. Balai Penelitian Niologi Laut. Jakarta: Pusat Penelitian dan Pengembangan Oseonologi-LIPI.

Rusli. 2006. Tipologi Makroalga pada Ekosistem Terumbu Karang di Tiga Pulau Kawasan Pulau Seribu DKI Jakarta. Institut Pertanian Bogor. Bogor.
Romimohtarto K. \& Juwana, S. 2007. Biologi Laut (Ilmu Pengetahuan Biota Laut). Jakarta: Djambatan

Sugiarto H., \& Supardi. 1995. Beberapa Catatan Bulu Babi Marga Diadema. Jurnal Oseana. 20(4):35-41.

Storlazzi, C.D., McManus, M.A. \& Figurski, J.D., 2003. Long-term, high-frequency current and temperature measurements along central California: insights into upwelling/relaxation and internal waves on the inner shelf. Continental Shelf Research, 23(9):901-918.

Thamrin. 2006. Karang. Biologi Reproduksi dan Ekologi. Minamandiri Press. Pekanbaru.

Timotius. 2003. Karakteristik Terumbu Karang. Makalah Training Course. Yayasan Terumbu Karang Indonesia.

Veron, J.E.N. 2000. Coralsoftheworld. AustralianInstituteof Marine Science. Townsville MC

Zakaria, I.J. 2013. Komunitas Bulu Babi (Echinoidea) di Pulau Cingkuak, Pulau Sikuai dan Pulau Setan Sumatera Barat. Prosiding SEMIRATA FMIPA Universitas Lampung. Lampung. 